\title{
エアシリンダ用リスク低減システムの開発
}

千葉 正伸*1，笹川 宏之*1，市川 修*1

\section{Development of a risk-reduction system for air cylinders}

\author{
Masanobu CHIBA $^{* 1}$, Hiroyuki SASAGAWA*1 and Osamu ICHIKAWA*1 \\ ${ }^{* 1}$ Polytechnic University \\ 2-32-1 Ogawa-nishimachi, Kodaira-shi, Tokyo 187-0035, Japan
}

Received: 10 July 2019; Revised: 25 October 2019; Accepted: 17 November 2019

\begin{abstract}
Industrial machinery accidents occupy a quarter of the whole accidents in manufacturing industry, and the ratio is increasing. In these accidents, some of the workers were killed or seriously injured when they were crushed or jammed by industrial machines since these machines have a big power. There are safeguarding equipments such as area sensors and guards at working areas of factories which prevent workers from hazards. Although these equipments are effective in automatic operation of the machines, they are often disabled during adjustment, cleaning, error recovery, or any other maintenance of machines. Many accidents are reported at non-routine work due to a human error when safeguarding was disabled. In order to make workplaces safe, the authors propose a risk-reduction system for air cylinders. The proposed system is attached to the rod end of a typical air-cylinder, and it makes a quick retract when a hand is mechanically detected at the end of the system. The system reduces possible crush risks from an air cylinder without using any external safeguarding system. This paper describes a novel structural principle of the proposed system. The performance of a prototype system is evaluated and the system is proved to be effective in reducing crush risks.
\end{abstract}

Keywords : Pneumatic system, Air cylinder, Crushed risk, Risk reduction

\section{1. 緒言}

機械設備による労働災害は依然として死傷災害全体の約 4 分の 1 を占め, 製造業では, その比率が増加傾向 (中 央労働災害防止協会，2018）にある．機械災害は，動力エネルギーが大きいことから，はさまれ，巻き込まれ， 押し潰されなどにより，身体の部位の切断，挫滅など，重篤な災害や死亡災害につながることが多いのが特徵と されている. 労働災害の全発生件数は，長期的には減少傾向にあるものの，定常作業以外の設備の点検や調整， 修理，清掃，トラブル対処などの非定常作業で発生する作業が多いため，災害が後を絶たない.

「化学設備の非定常作業における安全衛生対策のためのガイドラインの見直し」に関する調査研究報告書（化 学設備の非定常作業における安全衛生管理に関する調査委員会，2015）では，死亡災害の約 9 割が非定常作業で 発生しているとしている，一般に，定常作業では，ガードやエリアセンサにより危険区域内への侵入ができなく なっているが，これらを解除して危険区域内で作業を行う非定常作業では，些細な人間の行動エラーが事故災害 の要因となり得る.

本研究では，このような現状のもと，エアシリンダによる，はさまれ，押しつぶされ事故災害（ILO，2014）の リスク低減を目的とし，定常作業と非定常作業の両方に有効な「エアシリンダ用リスク低減システム」（以下，リ スク低減システムと略す）を開発した。このシステムは，一般的な複動エアシリンダのロッド先端に取り付け， 先端に手指などがはさまったときにエアシリンダを強制的に後退させるものである.ガード等の外部の装置に頼 ることなく，エアシリンダ自体のリスクを低減することができ，非定常作業時の災害防止効果が期待される。本

\footnotetext{
No.19-00282 [DOI:10.1299/transjsme.19-00282], J-STAGE Advance Publication date : 27 November, 2019

*1 正員，職業能力開発総合大学校（干187-0035 東京都小平市小川西町 2-32-1）

E-mail of corresponding author: m-chiba@uitec.ac.jp
} 
論文では，提案するリスク低減システムの構造と動作原理を示すとともに，手指がはさまれたときの残留リスク を評価し，リスク低減の効果が得られることを明らかにする。

\section{2. エアシリンダ用リスク低減システムの構成}

\section{$2 \cdot 1$ リスク低減システムの構造}

図 1 に本研究で新たに開発したリスク低減システムの全体構成を示寸。リスク低減システムは大別するとエア ヘッド部とコントロールバルブ部から成る. 本システムは物の押し込みや移動を目的とする一般的な複動エアシ リンダに取り付けが可能であり，エアシリンダによるはさまれ，押し潰されリスクの低減を行うものである．物 の押し込みや移動を目的とした場合，先端部を平面形状とするのが一般的であるが，これでは手指がはさまれた 場合に逃げることができない. そこで先端形状を円錐形とし, 治具 Jg との間に手指の逃げ空間を設けている.さ らに中心部に残されているリスクを低減するために, 図 1 で示すような中心部にエア遮断スプール Sp を配置し た. エアシリンダにより押し込まれる対象物の治具 $\mathrm{Jg}$ には，エア遮断スプール $\mathrm{Sp}$ の先端部分が逃げる小径穴を 設けておく.

図 2 に本システムの動作を示す，図 2(a), (b)は通常作業時の前進動作である. 図 2(a)は, エアシリンダが前進 し, エア遮断スプール Sp が治具 $\mathrm{Jg}$ の逃げ部に収まった状態を示している.さらにエアシリンダが前進すると,

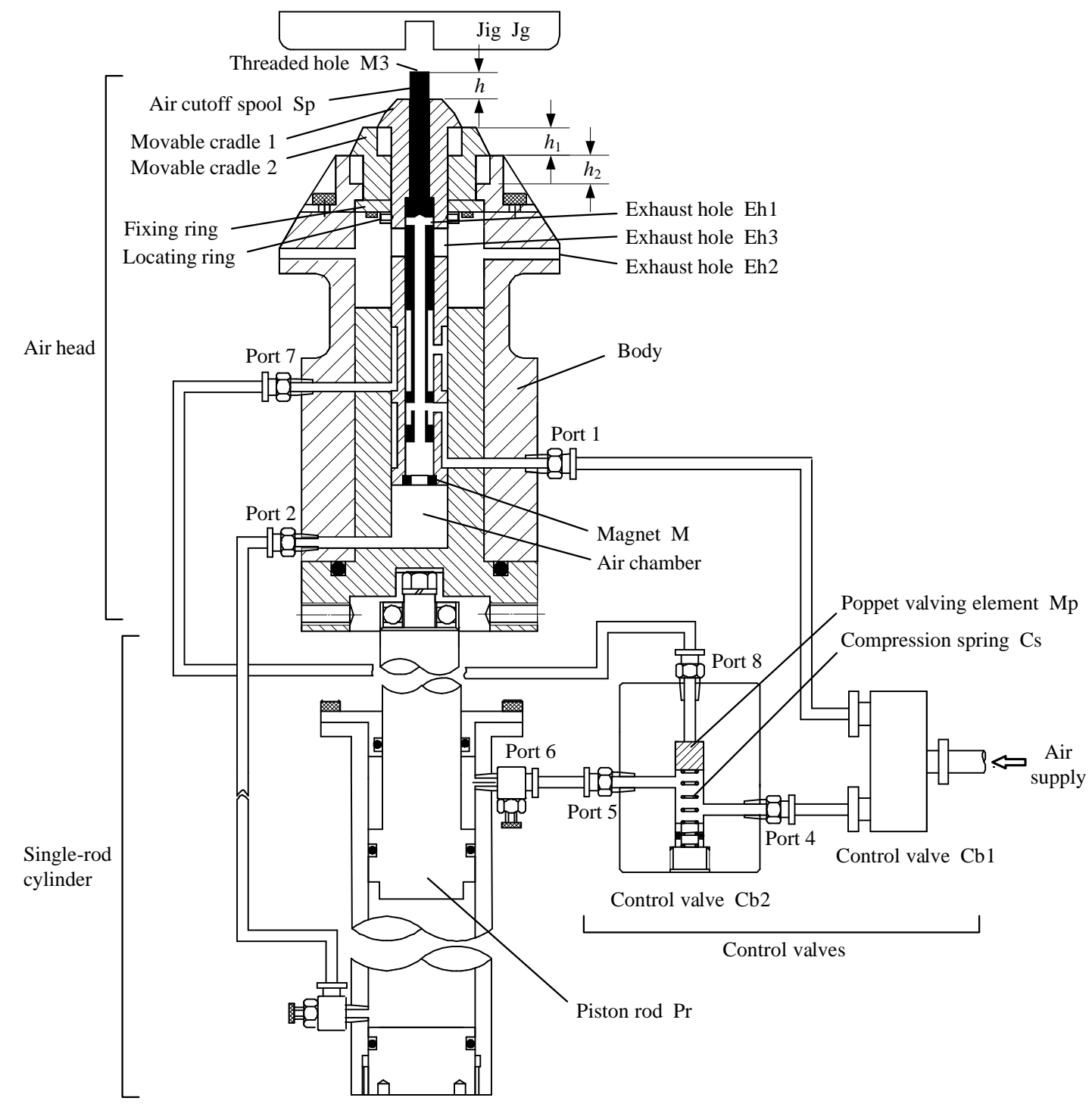

Fig. 1 Overall view of a risk-reduction system. 


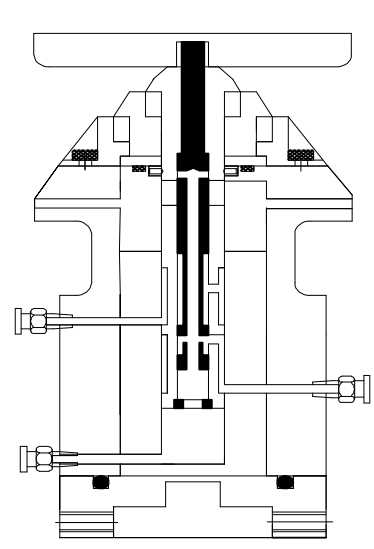

(a) Contact with the jig in normal operation.

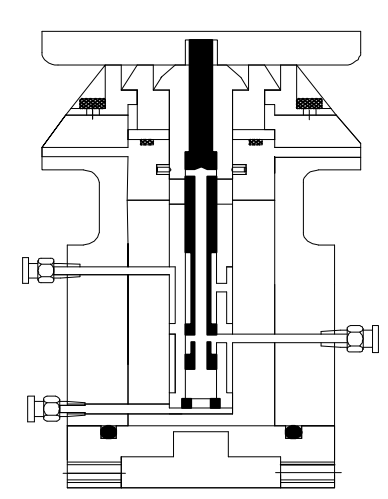

(b) Full contact with the jig in normal operation.
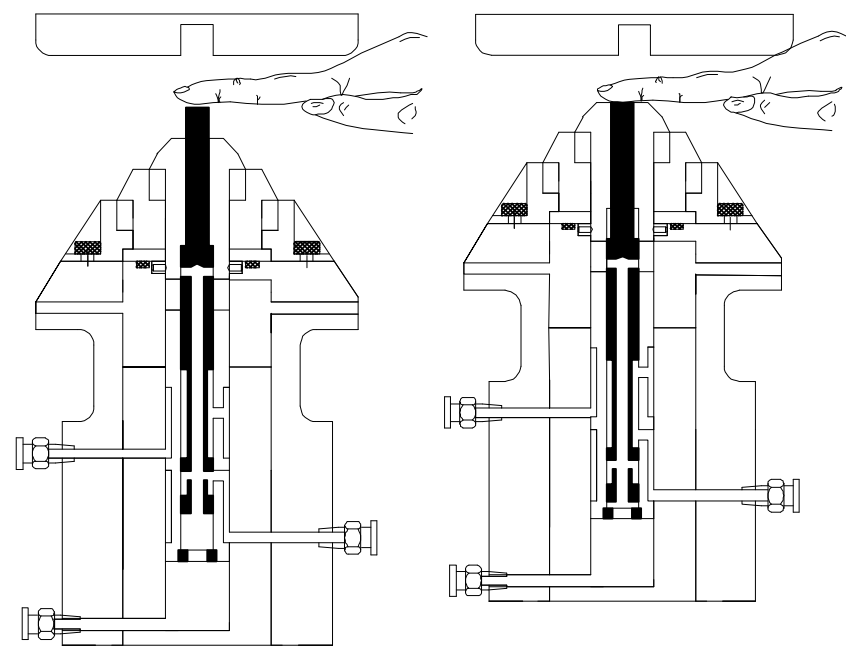

(c) A hand is approaching. (d) The crushed hand pushes the air cutoff spool.

Fig. 2 Behavior of the risk-reduction system.

可動受け台が後退してから治具を押し込む. 図 2(b)は可動受け台 1 および 2 が治具 Jg と全体接触した状態を示し ている. 図 2(c)，(d)は手指がはさまれた時の動作である. 図 2(c)ははさまれた瞬間の状態を示し，図 2(d)はエア 遮断スプール Sp が手指を介して押し込まれた状態を示す，スプール Sp が押し込まれると，エア遮断と同時にエ アシリンダ部が後退する. 図 1 のコントロールバルブ Cb2 は，エアシリンダの残圧を大気放出するための切換え 弁である（韓他，2001）。油空圧装置では, 残圧エネルギーが度々事故原因として問題となるが, 本開発のリスク 低減システムでは，残圧エネルギーがエアヘッド後退とともに完全に除去されるシステムである．このことは， ISO/IEC Giude51 に定める本質安全設計におけるエネルギー低減方策の指針と一致する。また本リスク低減シス テムは，すべて電子センサを用いないポジティブな構成である.

\section{$2 \cdot 2$ 通常作業時のシステムの動作}

リスク低減システムを取り付けたエアシリンダは, 手指がはさまれていないときは, 通常の前進・後退動作を 行う. 図 3 は図 1 のリスク低減システムを部分拡大したもので, 矢印はピストンロッドが前進寸る時のエアの流 れを示している. 通常時, エア遮断スプール Sp は前進し, 先端が突出している. ポート 1 から入力されたエア は, Air 室を経てポート 2 に伝達される.エアが Air 室に入るとエア遮断スプール Sp および可動受け台 1 がそれ ぞれ圧力を受け前進側に動く．ポート７はエア遮断スプール Sp によって遮断されている．この状態で可動受け 台 1 が治具 $\mathrm{Jg}$ に到達接触すると, 可動受け台 1 および可動受け台 2 が順次 D 面まで後退し, 図 2(b)で示すよう にエアヘッド本体の C 面でそれぞれの受け台が平面上に並ぶ. したがって治具 Jg との接触は A 面， B 面，C面 であり，これらの面が治具 Jg を押し込む方向に作用する. 図 3(b)はコントロールバルブ Cb2 のエアの流れを矢印 で示している. ポート 8 のエア圧力は低いため, 移動ポペット Mp は圧縮ばね Cs によって押し上げられ，ポート 5 から入ったエアはポート 4 から排出される. 図 4(a)に前進時の空気圧回路図を示す. コントロールバルブ $\mathrm{Cb} 1$ は，エアシリンダの前進・後退動作を切り換える電磁弁である. 電磁弁をオンすると太線の経路で圧縮エアが供 給され, エアシリンダが前進する. スプール Sp とコントロールバルブ $\mathrm{Cb} 2$ は, 通常作業時は操作されない. 図 4(b)は後退時の空気圧回路図である. コントロールバルブ $\mathrm{Cb} 1$ をオフすると, コントロールバルブ $\mathrm{Cb} 2$ のポート 4 に圧縮エアが供給され, ポート 5 , ポート 6 と伝達されロッドは後退する. 


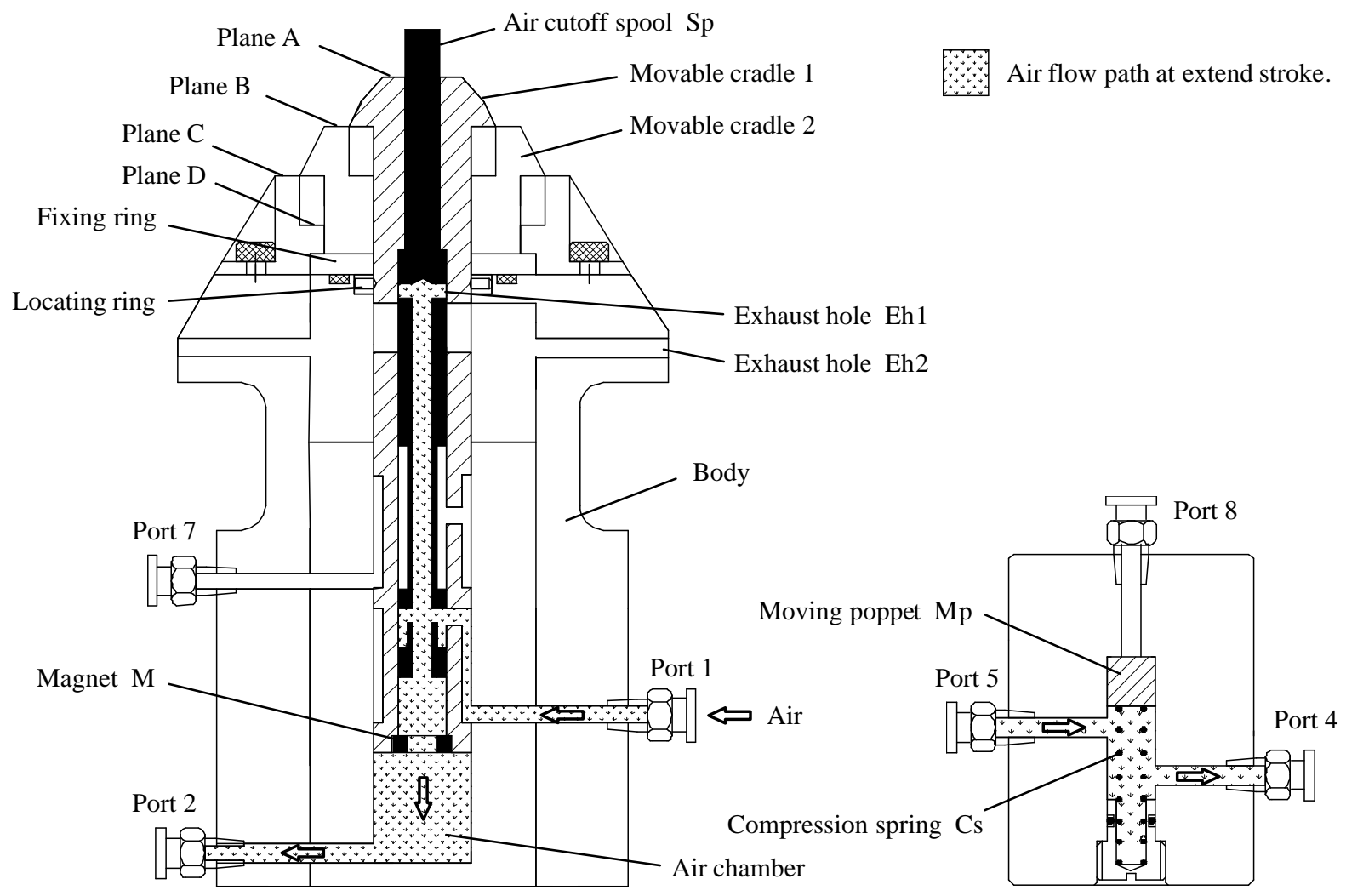

(a) Air head.

(b) Control valve $\mathrm{Cb} 2$.

Fig. 3 Air flow path in normal operation.

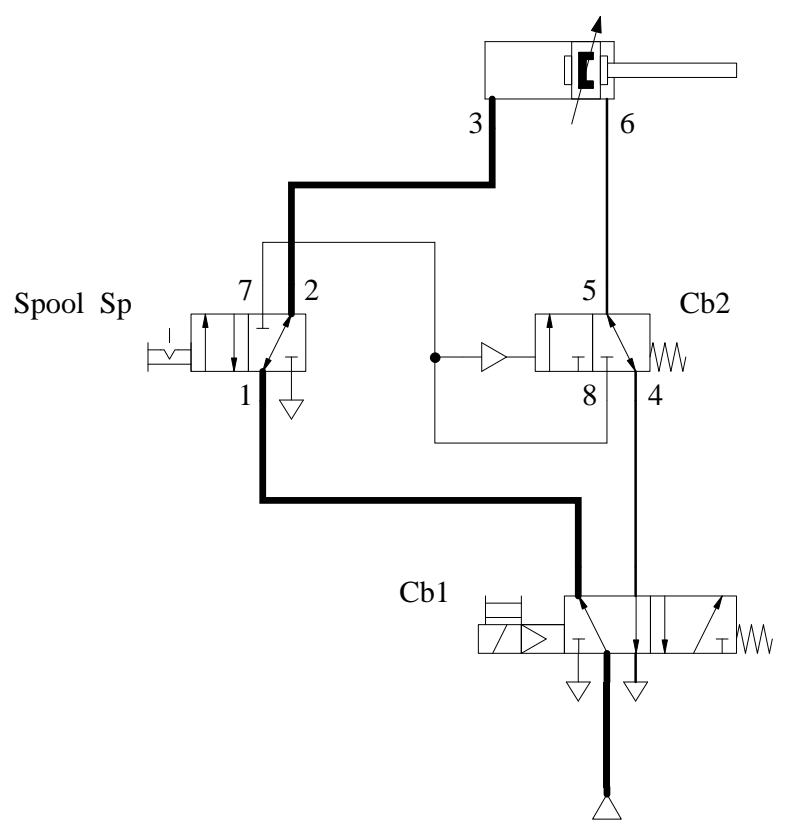

(a) Cylinder extend stroke.

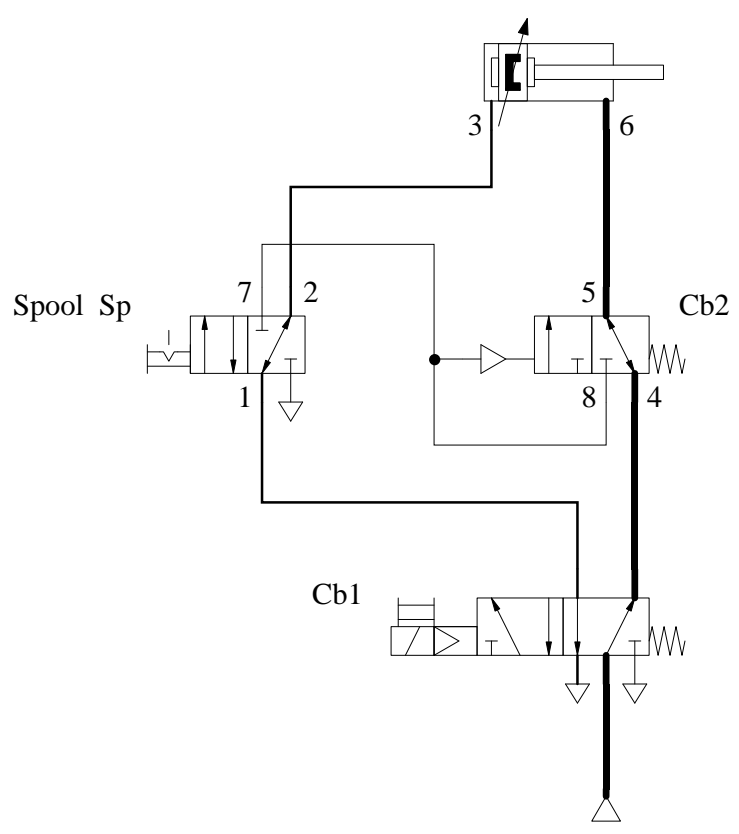

(b) Cylinder retract stroke.

Fig. 4 Pneumatic circuit diagrams in normal operation. 


\section{$2 \cdot 3$ 手指がはさまれた時のシステムの動作}

はさまれリスクは，ピストンロッドPrが前進する場合に発生する. 人間の誤りや設備の不具合等により, 治具 $\mathrm{Jg}$ とエア遮断スプール Sp の間で手指がはさまれた場合, 手指を介してエア遮断スプール Sp が押し込まれ, ス プールは磁石 $\mathrm{M}$ により固定される. 磁石 $\mathrm{M}$ は可動受け台 1 の底面に置かれ, エア遮断スプール $\mathrm{Sp}$ の上昇誤動作 を防止するために設置してある. エア遮断スプール Sp は可動量 $h$ を設けてあり, この可動量の間で空気圧回路 が切り替えられる.

図 5 は手指がはさまれたときのエアヘッド部の状態とエアの流れを示寸. 手指によってエア遮断スプール $\mathrm{Sp}$ が押し込まれると，ポート1 から入力されたエアはスプールの働きによりポート 7 から出力される. 同時にポー ト2 のエアは, エア逃がし穴Eh1, Eh3, Eh2 を通り排気される. また, ポート 7 を経由してコントロールバルブ $\mathrm{Cb} 2$ のポート 8 に供給されたエアは，図 5(b)に示寸移動ポペット $\mathrm{Mp}$ と圧縮ばね $\mathrm{Cs}$ (新谷他，2014）を押し下げ てポート 4 を閉じ，ポート 5 から出力される．移動ポペット Mp がポート 4 からの大気放出を封鎖する役割を持 ち，エアは全てピストンロッドPr後退に供給される.

図 6 に手指がはさまれたときの空気圧回路図を示す.エア遮断スプール Sp によって切り換えられたエアは, コントロールバルブを操作するとともに, ピストンロッド Pr を後退させる. このとき, シリンダのキャップ側に 蓄積した残圧は，ポート 2 を経由してエアヘッドのエア逃がし穴から大気放出される.

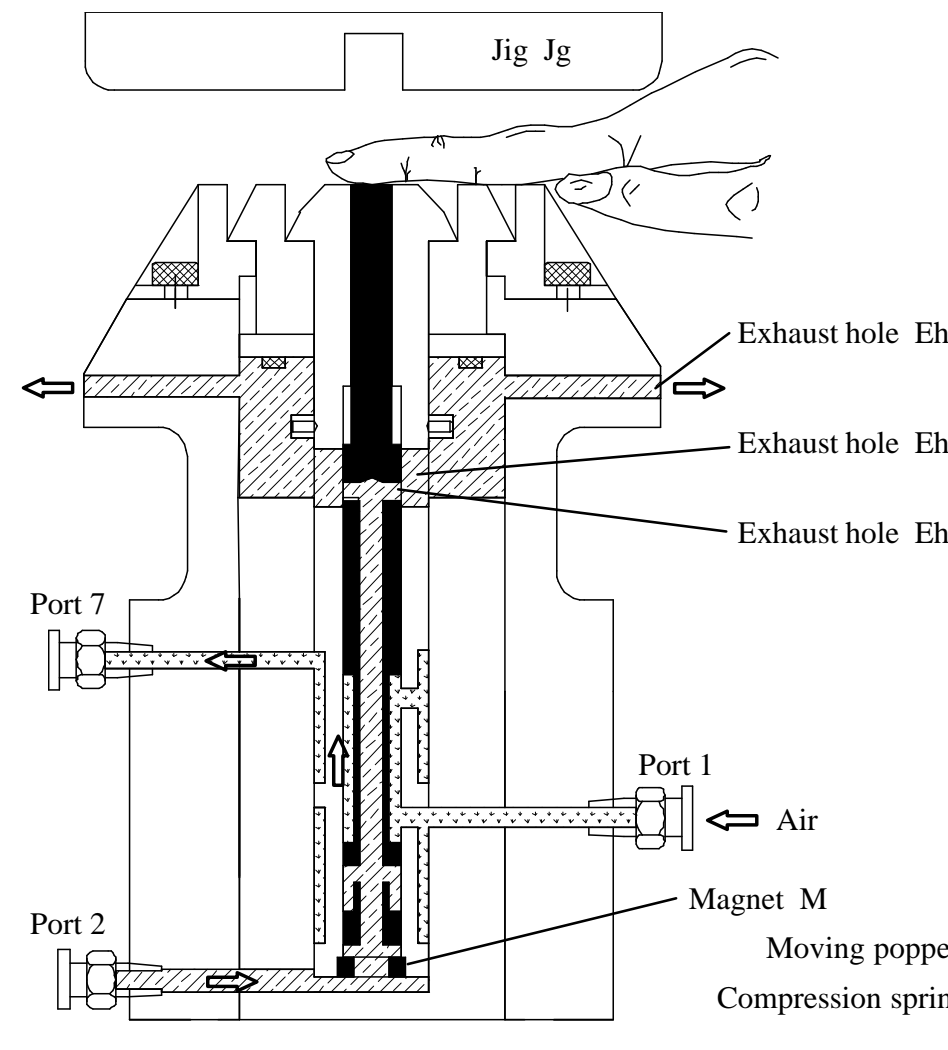

(a) Air head.
Air flow path before crushing.

Air flow path after crushed.

Fig. 5 Air flow path after the crushed hand pushed the air cutoff valve. 


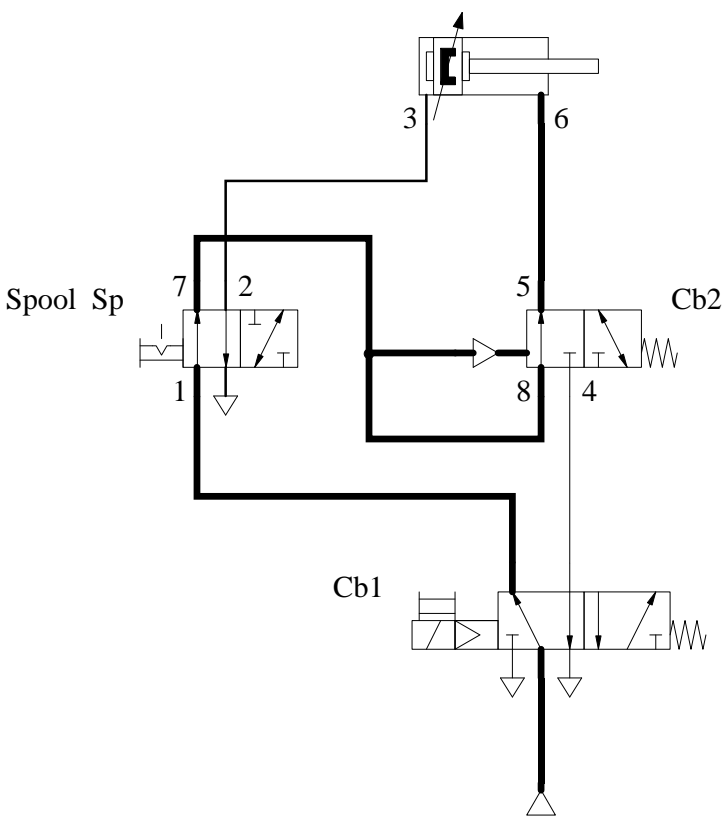

Fig. 6 Pneumatic circuit diagram when the spool Sp is pushed.

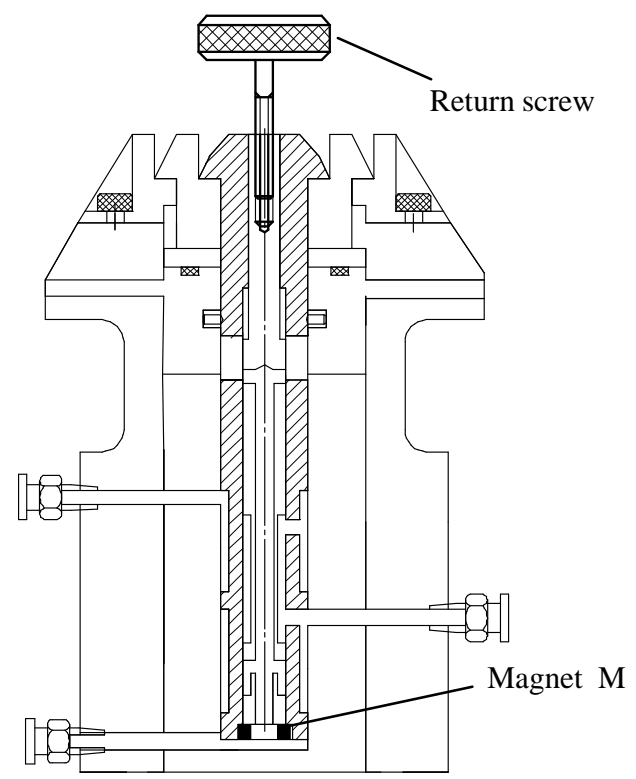

Fig. 7 System recovery by the return screw.

\section{2 - 4 復帰操作}

図 7 はエア遮断スプール Sp が押し込まれた状態である. エア遮断スプール Sp は, 一度押し込まれると, 磁石 M の働きにより動作が保持される．空気圧回路の働きにより，エアシリンダは後退している.

システムを復帰するには，まずエアシリンダの前進操作をしていたコントロールバルブ $\mathrm{Cb} 1$ をオフする．これ によりコントロールバルブ Cb2 を操作していたエアが排気され， Cb2 の移動ポペットが復帰する. 次に復帰専用 漦じを使用してエアヘッドの磁石 M の吸着解除を行う。これにより, エアシリンダが後退した状態で復帰操作が 完了する.

復帰手順を誤り, コントロールバルブ $\mathrm{Cb} 1$ をオンにしたまま, エアヘッドの磁石 $\mathrm{M}$ の吸着解除を行った場合, コントロールバルブ Cb2 を操作していたエアは排気されない. 従って Cb2 の動作は保持されるため, エアシリン ダが前進することはない，もしエアシリンダが再動作して前進すると，再び手指がはさまれることになるが，本 システムは復帰手順の誤りに対して安全性が確保されている.なお，復帰手順を誤っても，再びエア遮断スプー ル Sp を押し込んでから正しい手順に従えば，復帰操作は完了する.

\section{3. 残留リスクの評価}

\section{$3 \cdot 1$ 評価対象とする試作システム}

提案するリスク低減システムの残留リスクを評価するため，システムを設計・試作した．リスク低減を行う対

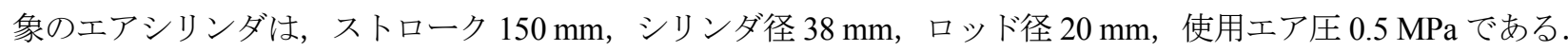

中心部以外ではさまた場合のリスク低減として，円錐形状によるリスク低減を採用した．図 8 は手指がはさま れた状態を示すものであり， 円錐形状上の先端に手指が載らない輪体厚さ $L$ と逃げ角 $\alpha$ 重要となる. 手指にお ける爪の計測（吉田，1996）等の先行研究を参考に, 著者および数人による試行実験を行い, 治具 $\mathrm{Jg}$ とエアヘッ ド部にはさまれることなく手指が滑り落ちる角度を求めた，実験より，輪体厚さ $L$ は $4 \mathrm{~mm} \sim 6 \mathrm{~mm}$, 逃げ角 $\alpha$ は $56^{\circ} \sim 60^{\circ}$ が妥当であることを明らかにした. 本開発では, $L=5 \mathrm{~mm}, \alpha=56^{\circ}$ を採用し, その先端をさらに 面取りし，指が滑り落ちや寸くした。

中心部ではさまれた場合, エア遮断スプール Sp によりエアは遮断されるが, 慣性力により前進するリスクが 残されている．この慣性力の前進量は，可動受け台 1 および 2 がそれぞれ連動して後退側に動くことにより打ち 消される. また図 2(b)において治具 $\mathrm{Jg}$ との安定接触を目的とすると, 可動受け台の複数化が必要とされる. 本開 


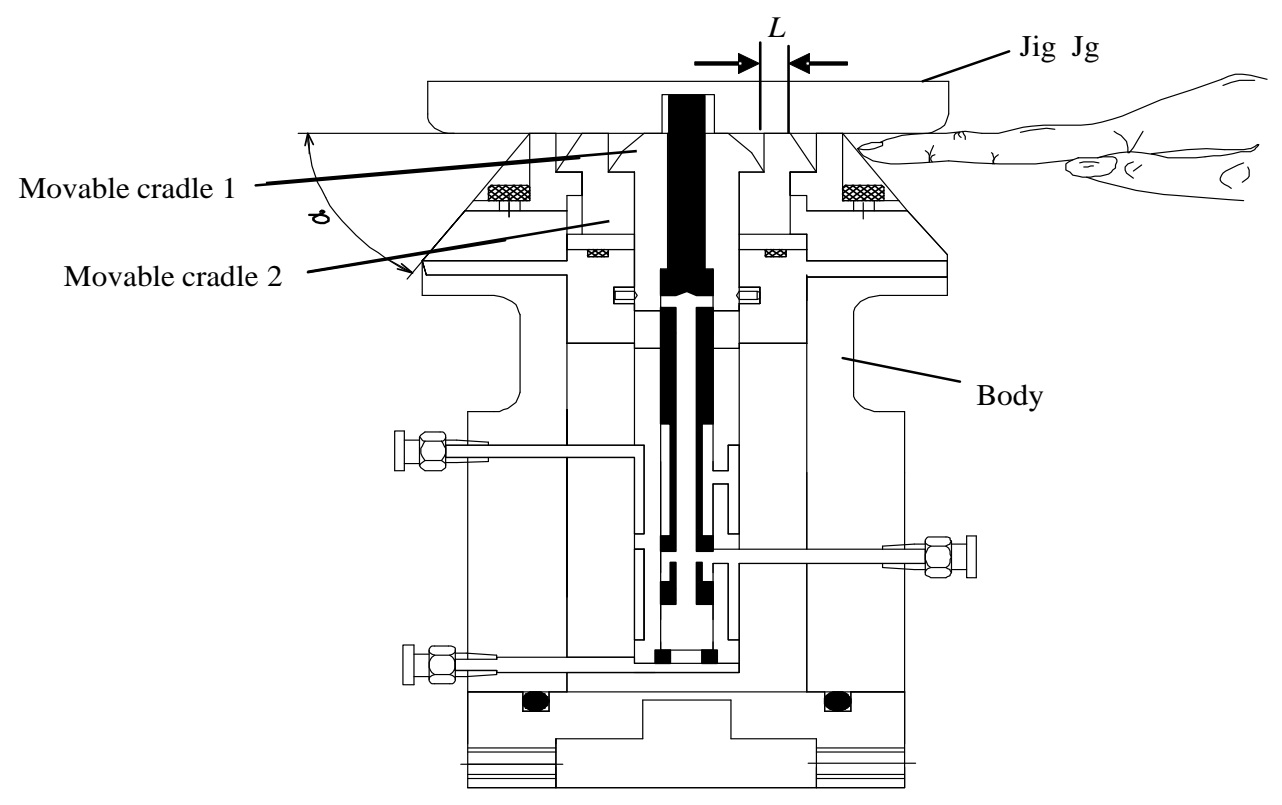

Fig. 8 Risk reduction with conical cradles.

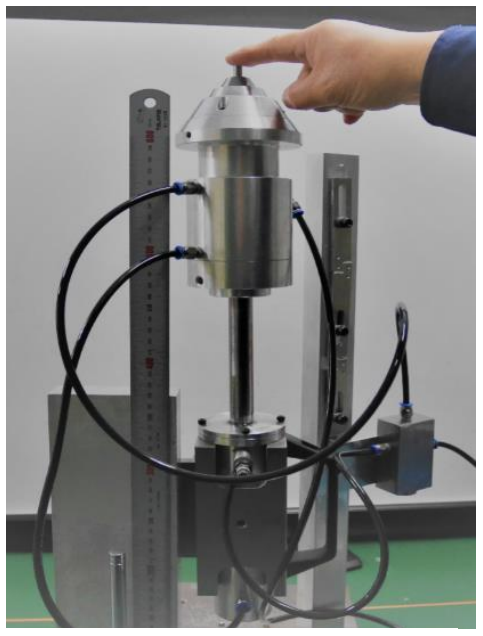

(a) A hand is approaching.

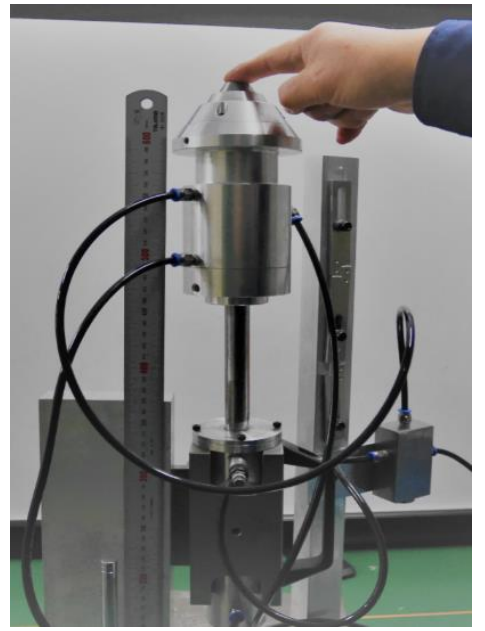

(b) A hand pushes the air cutoff spool Sp.

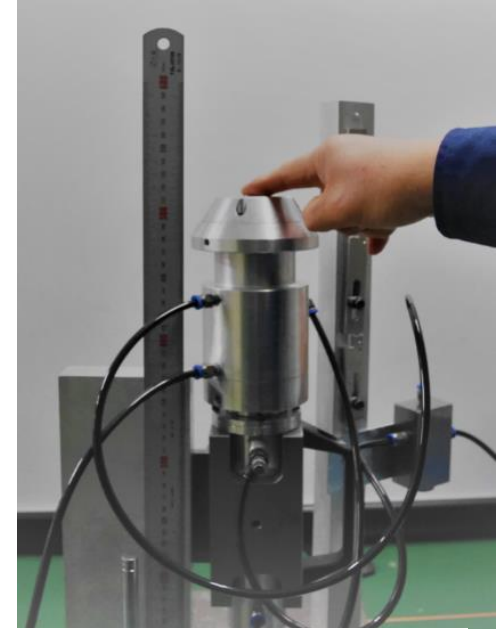

(c) Cylinder is retracted.

Fig. 9 Behavior of a prototype.

発では可動受け台 1 および 2 の可動長さ $h_{1}, h_{2}$ は, 慣性力による行き過ぎ量を考慮しそれぞれ $10 \mathrm{~mm}$ とし，合 計 $20 \mathrm{~mm}$ の可動長さとした。つまり，エアヘッドは $20 \mathrm{~mm}$ の行き過ぎが許容される.

\section{$3 \cdot 2$ 慣性カによる押しつぶされリスクの検討}

本システムの押しつぶされリスクを評価するために，3.1 節で設計した寸法の装置を試作した. 図 9 に試作機 の各動作状態における写真を示す。図 9(a)はシリンダ前進中に手指が近付いた状態，図 9(b)は手指によってエア 遮断スプール Sp が押し込まれた状態, 図 9(c)はスプールの働きによりエアシリンダが後退した状態である. 手指 に押しつぶしの力をかけることなく, エアシリンダが後退することを確認した.

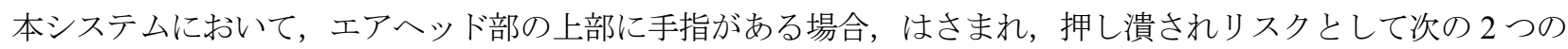
状態が考えられる，それぞれについて定量的な検討を行う。 
(1) 前進中にエア遮断スプール Sp が手指に接触する

(2) エア遮断スプール Spの操作によって, エアシリンダが前進から後退に転じる際，エアヘッド部に行き過ぎ が生じる

\section{$3 \cdot 2 \cdot 1$ エア遮断スプール Sp の先端が手指に接触する際の挙動}

本体可動部の質量を $M[\mathrm{~kg}]$, 加速度を $a\left[\mathrm{~m} / \mathrm{s}^{2}\right]$, 重力加速度を $\mathrm{g}\left[\mathrm{m} / \mathrm{s}^{2}\right]$ とすると, 運動方程式は式(1)で表される.

$$
M a=F-F_{f}-M g
$$

ここで $\mathrm{F}$ は上昇時のエア圧による力， $F_{\mathrm{f}}$ はその時の摩擦力である. エアヘッド部が $t=0$ の停止状態から上昇を開 始し，手指に接触してスプールが押し込まれるまでの時間を $t_{1}$ とおくと，そのときのストローク $S_{1}$ と速度 $V_{1}$ は， それぞれ次式で表される.

$$
\begin{aligned}
& S_{1}=\frac{1}{2} a t_{1}^{2} \\
& V_{1}=a t_{1}=\sqrt{2 S_{1}\left(\frac{F-F_{f}}{M}-g\right)}
\end{aligned}
$$

次に, 図 10 のように手指がエア遮断スプール Sp を押し込むための力 $F_{\mathrm{s}}$ にいて計算する. 速度 $V_{1}$ で運動し ている質量 $m_{\mathrm{s}}$ のエア遮断スプール Sp を $\Delta t$ 秒間で停止させるために必要な力を $F_{2 \mathrm{u}}$, 断面積 $A_{\mathrm{s}}\left[\mathrm{m}^{2}\right]$, シリンダ内 の圧力 $P\left[\mathrm{~N} / \mathrm{m}^{2}\right]$ のエア遮断スプール $\mathrm{Sp}$ を押し込むために必要な力を $F_{2 \mathrm{a}}$ とおくと, 手指に加わる力 $F_{\mathrm{s}}$ は

$$
F_{S}=F_{2 u}+F_{2 a}=\frac{m_{s} V_{1}}{\Delta t}+A_{s} P=\frac{m_{s}}{\Delta t} \sqrt{2 S_{1}\left(\frac{F-F_{f}}{M}-g\right)}+A_{s} P
$$

となる. ここで, $V_{1}$ が最も大きくなるシリンダ前進端の位置 $S_{1}=150 \mathrm{~mm}$ において, 手指に加わる力を求める. エア圧による推力 $F$ はピストンの運動に応じて減少する可能性があるが, これらの減少がないものとする.また, $\Delta t$ については厳しめに考えて $\Delta t=0.1 \mathrm{~s}$ とする.

今回設計した装置の諸元を式(4)に代入すると, 手指に加わる力 $F_{\mathrm{s}}$ は $40 \mathrm{~N}$ と求まる.「人間の痛覚而性值の評 価」（山田，杉本，1995）によると手指の静的接触力による而性值は $50 \mathrm{~N} \sim 180 \mathrm{~N}$ 程度であり，短時間の接触力に よる而性値はさらに高い. 従って設計した装置においてはさまれた手指に加わる力は, 許容される大きさである.

\section{$3 \cdot 2 \cdot 2$ エアヘッド部の行き過ぎ量}

上昇するエアヘッド部と治具 $\mathrm{Jg}$ の間に手指がはさまれた場合，エア遮断スプール $\mathrm{Sp}$ が押されエアヘッド部に 後退の力が加わる. しかし，エアヘッド部の速度は瞬時には負にならない．手指がエアヘッドに接触してスプー ルを押し込んだ時間 $t_{1}$ より後は, 瞬時に上向きの圧力が遮断され, 下方への圧力が加わるため, スプールを押し 込んだ位置からのピストンロッド $P r$ 変位 $X_{3}$ は次式で求められる.

$$
\begin{aligned}
X_{3} & =V_{1}\left(t-t_{1}\right)+\frac{1}{2}\left(-\frac{F_{3}}{M}-g\right)\left(t-t_{1}\right)^{2} \\
& =\sqrt{2 S_{1}\left(\frac{F-F_{f}}{M}-g\right)\left(t-t_{1}\right)-\frac{1}{2}\left(\frac{F_{3}}{M}+g\right)\left(t-t_{1}\right)^{2}}
\end{aligned}
$$




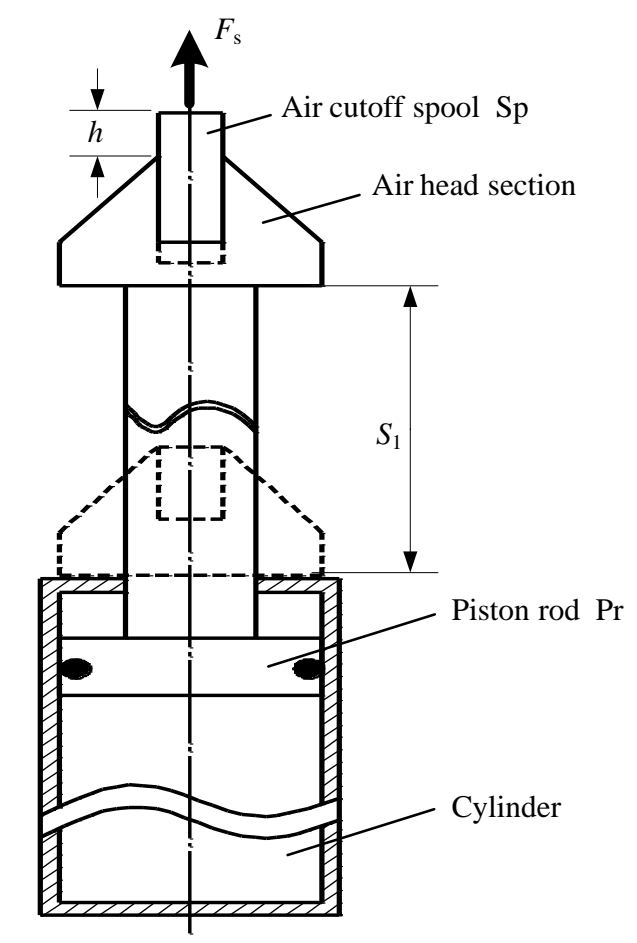

Fig. 10 Force applied to a hand by the air cutoff spool Sp.

ただし， $F_{3}$ は下向きの推力である.

今回の諸元を式(6)に代入すると，手指が接触してスプールを押し込んだ後のシリンダヘッドの変位は図 11 の ようになる，手指がはさまれた後，エア遮断スプール Sp が切り変えられるが，慣性力により 0.07 秒後に $1.1 \mathrm{~mm}$ の行き過ぎがあり，その後変位は減少に転じる，手指がはさまれた場合の逃げ余裕長さ $h_{1}$ および $h_{2}$ をそれぞれ $10 \mathrm{~mm}$ ，合計で $20 \mathrm{~mm}$ 取っているのに対し，行き過ぎがこの範囲内であるため，十分に安全である.

\section{$3 \cdot 3$ リスク低減システムの安全性の検証}

表 1 は図 1 のシステムの作動状態を示すための論理変数と論理值の意味を示している. Sp は手指がはさまれた とき，切り換えられる状態の有無を表す論理変数である.

2 值で示された $\mathrm{Sp}, \mathrm{Mp}^{*}, \mathrm{Cs}^{*}, \mathrm{Pr}^{*} の$ 全ての組合せ状態は 16 通り存在するが，手指がはさまれる状態で, $\mathrm{Sp}=1$ のとき $\mathrm{Mp}^{*}, \mathrm{Cs}^{*}, \mathrm{Pr}^{*}$ が論理值 1 または 0 のすべての組み合わせは，安全側故障である。つまり $\mathrm{Sp} \geqq \operatorname{Pr} *$ の関係 は許される関係である.

一方， $\mathrm{Sp}=0$ ，のとき $\mathrm{Mp}$ *および $\mathrm{Cs}$ *にはエアは伝達されない. この状態において $\mathrm{Pr}^{*}=0$ の組み合わせは安全側 故障であるが, $\mathrm{Pr}^{*}=1$ の組合せ，すなわち $\mathrm{Sp}<\mathrm{Pr}$ *の関係だけは許さないシステムである．これらをまとめたもの を表 2 に示寸.

$\mathrm{Sp}<\operatorname{Pr} *$ 以外の許される 3 通りの論理的関係は，表 2 に示寸ように, $\mathrm{Sp} \geqq \operatorname{Pr}$ の論理的関係で示される. 
Chiba, Sasagawa and Ichikawa, Transactions of the JSME (in Japanese), Vol.85, No.880 (2019)

Table 1 Logical variables assigned to the operating state of the risk reduction system.

\begin{tabular}{|c|c|l|}
\hline Logical variable & Logical value & \multicolumn{1}{|c|}{ Meaning of logical value } \\
\hline \multirow{2}{*}{$\mathrm{Sp}$} & 1 & $\begin{array}{l}\text { When a hand and is sandwicheded,the spool operates } \\
\text { properly. }\end{array}$ \\
\cline { 2 - 3 } & 0 & $\begin{array}{l}\text { When a hand and a finger are sandwiched, the valve does } \\
\text { not operate properly. }\end{array}$ \\
\hline \multirow{2}{*}{$\mathrm{Mp}^{*}$} & 1 & Poppet valve operates properly. \\
\cline { 2 - 3 } & 0 & Poppet does not operate properly. \\
\hline \multirow{2}{*}{$\mathrm{Cs}^{*}$} & 1 & Compression spring works properly. \\
\cline { 2 - 3 } & 0 & Compression spring does not work properly. \\
\hline \multirow{2}{*}{$\operatorname{Pr}^{*}$} & 1 & Piston rod operates properly. \\
\cline { 2 - 3 } & 0 & Piston rod does not operate properly. \\
\hline
\end{tabular}

Table 2 Relationship between Sp and Pr*.

\begin{tabular}{|c|c|c|}
\hline $\mathrm{Sp}$ & $\mathrm{Pr}^{*}$ & \multicolumn{1}{|}{ Logical relationship } \\
\hline 1 & 1 & \multirow{2}{*}{$\mathrm{Sp} \geqq \operatorname{Pr}$ (Permissible relationships.) } \\
\hline 1 & 0 & \\
\hline 0 & 0 & $\mathrm{Sp}<\operatorname{Pr}$ (Unforgivable relationships.) \\
\hline 0 & 1 &
\end{tabular}

本システムにおいて，エア遮断スプール Sp の作動状態と，ピストンロット Pr*の後退の論理的関係は式 7 の関 係でなければならない.

$$
\mathrm{Sp} \geqq \operatorname{Pr} *
$$

$\mathrm{Sp}<\operatorname{Pr} *$ 状態は，エア遮断スプール Sp の固着が考えられるものの，固着に対する信頼性確保は，経験的に十 分に吟味された部品を使用し, かつ, 十分に品質管理することにより対処できる. 特にエア遮断スプール $\mathrm{Sp}$ は, 始業前点検時において，作動が最初に確認できる部位であり，固着等を見落とすことはない. 


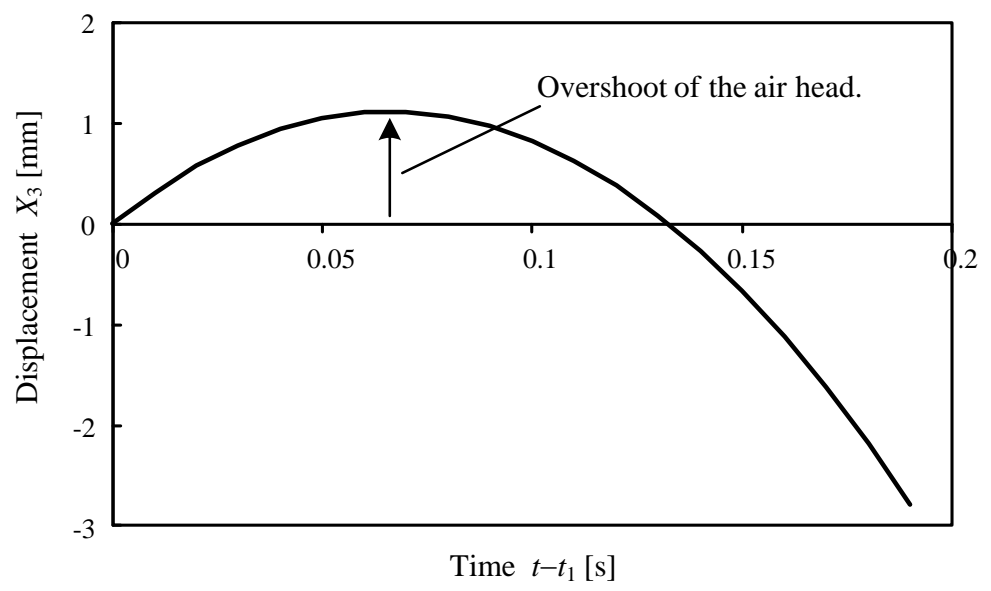

Fig. 11 Displacement of the air head after the spool Sp is pushed.

\section{4. 結 言}

エアシリンダによる，はさまれ，押し潰され災害の低減を目的としたエアシリンダ用リスク低減システムを新 しく提案し，設計試作をした，自動生産設備では，安全を確保するためにセンサによる監視が可能であるが，不 具合が発生した時に，センサを解除し修理点検，調整を行う場合がある．この時，人間の注意力のみが危険を回 避する方法となる. 人間はエラー犯すと定義（向殿，2000）すると，いずれは重大事故を招きかねない．そこで 本研究では，定常作業はもとより非定常作業時にもはさまれ，押し潰され災害に有効なエアシリンダ用リスク低 減システムを開発した.

本研究において得た主たる結論は以下の通りである.

（1）本システムは，市販されている一般的なエアシリンダに取り付けが可能であり，汎用性がある.

（2）手指がはさまれると，エア遮断スプール Spの作動により，エアヘッドが後退する．行き過ぎは設計值の 範囲内であることを, 理論及び実験から明らかにした. またエアヘッのド円錐形状もリスク低減効果をもたらす.

（3）本システムは，センサ等を使用していないため, 電気的な情報伝達が不要である. また付加保護方策指針 に定める，エネルギーを遮断し残留エネルギーを消散する方策となっている.

（4）空気圧機器においては，残圧による事故が問題となる場合が多いが，本システムは，エア遮断スプール $\mathrm{Sp}$ のロックを解除しても，移動ポペットの働きにより，突然の起動はしない安全機構を成している.

\section{文献}

中央労働災害防止協会,安全の指標 (2018).

韓保軍, 藤田壽憲, 川嶋健嗣, 香川利春, 圧力条件が空気圧機器の流量特性に与える影響, 日本油空圧学会論文集,

Vol. 32, No. 6 (2001), pp.143-149.

ILO 編,小木和孝訳, 人間工学チェックポイント, 労働科学研究所 (2014), pp.10-35.

化学設備の非定常作業における安全衛生管理に関寸る調查委員会, 化学設備の非定常作業における安全衛生対策 のためのガイドラインの見直し (2015).

向殿政男, これからの安全技術, 中央労働災害防止協会 (2000), pp.22-39.

新谷紀雄, 杉山充弘, 伊藤晃輔, 上田三千雄, 内田一利, 本間達, 古澤寛行, 若林豊, 圧縮コイルばねのへたりに関 する研究委員会報告, ばね論文集, No. 59 (2014), pp.47-62.

山田陽滋, 杉本旭, 人間の痛覚而性の評価, 日本ロボット学会誌, Vol. 13, No. 5 (1995), pp.639-642.

吉田太, 手指における爪, 指末節部, 指末節骨の計測のよる形態学的研究, 昭和医学会雑誌, Vol. 56, No. 2 (1996), pp.175-182. 


\section{References}

Central Labor Accident Prevention Association, Indicators of safety (2018) (in Japanese).

Han, B., Fujita, T., Kawashima, K. and Kagawa, T., Influence of pressure condition change on the flow rate characteristics of pneumatic valve, Transactions of The Japan Hydraulics \& Pneumatics Society, Vol. 32, No. 6 (2001), pp.143-149 (in Japanese).

ILO ed., Ogi, K. tr., Ergonomics Checkpoint, The Institute for Science of Labour (2014), pp.10-35 (in Japanese).

Investigation committee on safety and hygiene management in chemical equipment unsteady work, Review of guidelines for safety and hygiene measures in unsteady work of chemical equipment (2015) (in Japanese).

Mukaidono, M., Future safety technology, Japan Industrial Safety \& Health Association (2000), pp.22-39 (in Japanese).

Shintani, N., Sugiyama, M., Ito, K., Ueda, M., Uchida, K., Honma, T., Furusawa, H. and Wakabayashi, Y., Report of research committee on height reduction of compressed coil spring, Transactions of Japan Society of Spring Engineers, No. 59 (2014), pp.47-62 (in Japanese).

Yamada, Y. and Sugimoto, N., Evaluation of human pain tolerance, Journal of the Robotics Society of Japan ,Vol. 13, No. 5 (1995), pp.639-642 (in Japanese).

Yoshida, F., Morphologic study of the finger nail, distal portion of the digit, and distal phalanx, Journal of The Showa Medical Association, Vol. 56, No. 2 (1996), pp.175-182 (in Japanese). 